\title{
Dispersal and dispersion of southern elephant seals in the Kerguelen province, Southern Ocean
}

\author{
W. CHRIS OOSTHUIZEN ${ }^{1}$, MARTHÁN N. BESTER ${ }^{1}$, CHERYL A. TOSH ${ }^{1}$, CHRISTOPHE GUINET $^{2}$, \\ DOMINIQUE BESSON ${ }^{2}$ and P.J. NICO DE BRUYN ${ }^{1}$ \\ ${ }^{I}$ Mammal Research Institute, Department of Zoology and Entomology, University of Pretoria, Private Bag X20, Hatfield, \\ Pretoria 00028, South Africa \\ ${ }^{2}$ Centre d'Etudes Biologiques de Chize, Centre National de la Recherche Scientifique, F-79360 Villiers en Bois, France \\ wcoosthuizen@zoology.up.ac.za
}

\begin{abstract}
Southern elephant seals Mirounga leonina within the Kerguelen province disperse between Marion Island (MI), Iles Crozet (IC) and Iles Kerguelen (IK) despite the high site fidelity characteristic of this species. From 1987-2002, 199 IC individuals, or $11.63 \%$ of the tagged population there, were resighted at MI. Resights of IC seals at MI peaked during the juvenile moult and seals aged 0-2 represent $66 \%$ of all resights made. Equal numbers of male and female seals (all age classes) were dispersing. Dispersing breeding females ( $n=22$, on 33 occasions) outnumbered dispersing breeding males ( $n=6$, on 16 occasions), after initially emigrating from IC to MI as juvenile seals (natal dispersal). Greater male-mediated gene flow was ultimately attained due to the polygynous mating system and some extremely successful males. Of 132 seals fitted with satellite-relay data loggers at MI, six hauled out at IC and three at IK. Two of the seals which migrated to IC were born at MI; all others were unmarked males likely to be native to IC or IK. Dispersal should ideally be considered when assessing vital rates for southern Indian Ocean elephant seal populations.
\end{abstract}

Received 6 October 2010, accepted 26 April 2011, first published online 20 July 2011

Key words: gene flow, Iles Crozet, Iles Kerguelen, mark-resighting, metapopulation, migration, Mirounga leonina, Marion Island

\section{Introduction}

The movement of organisms from one location to another is a fundamental biological process shaping the distribution, structure and dynamics of populations and ultimately influencing communities (Nathan 2001). Dispersal, defined as the movement of an organism from its birth site to a site where it reproduces, or would have reproduced if it survived and had access to a mate (Howard 1960), affects both local and global population dynamics by modifying the composition of populations (Clobert et al. 2001). Specifically, natal dispersal (the movement from the natal site to the site where reproduction is first attempted) can be distinguished from breeding dispersal, the latter which is defined as a change in breeding sites between two successive breeding attempts (Greenwood 1980). Long distance dispersal events are especially important to maintain genetic connectivity between populations and although occurring at low frequency, such events have disproportionate impact on populations (Nathan 2001, Trakhtenbrot et al. 2005). Dispersal - through the processes of individual movement, survival and reproduction - thus maintains metapopulation structures and enables gene flow between distant sites, influencing the geographical distribution and persistence of populations (Clobert et al. 2001, Nathan 2001).

An alternative strategy to dispersal is known as philopatry, where individuals are faithful to the natal site and attempt to reproduce at the natal site or recruit to the natal colony (Greenwood 1980). Movements away from the natal site are then associated with non-reproductive purposes, for example foraging. Migration is defined as a periodic (cyclic or seasonal) departure and return (i.e. it involves a return trip), to be distinguished from immigration and emigration, which are one-way inward and one-way outward processes respectively (Van den Hoff 2001). Dispersion, defined by Nicholls (1970) as "the changing distribution during the life of an animal", is used here to describe the presence of individuals at a non-natal site for non-reproductive purposes.

Southern elephant seals (Mirounga leonina L.) have a circumpolar distribution in the Southern Ocean (McMahon et al. 2005a). A consistent decline in populations across large parts of the species, range (Indian and Pacific oceans) between the 1950s and 1990s resulted in several studies assessing not only population size (e.g. Authier et al. 2011) but also the potential drivers of such change in population size for this top predator (reviewed by McMahon et al. 2005a). Furthermore, elephant seals are important model species to help understand the interplay between the physical and biological environment, prey and predator (e.g. McConnell et al. 1992, Bailleul et al. 2007).

All southern elephant seals migrate annually between terrestrial haulout sites (where they may breed, moult or winter) and pelagic foraging areas. During the pelagic phase, 


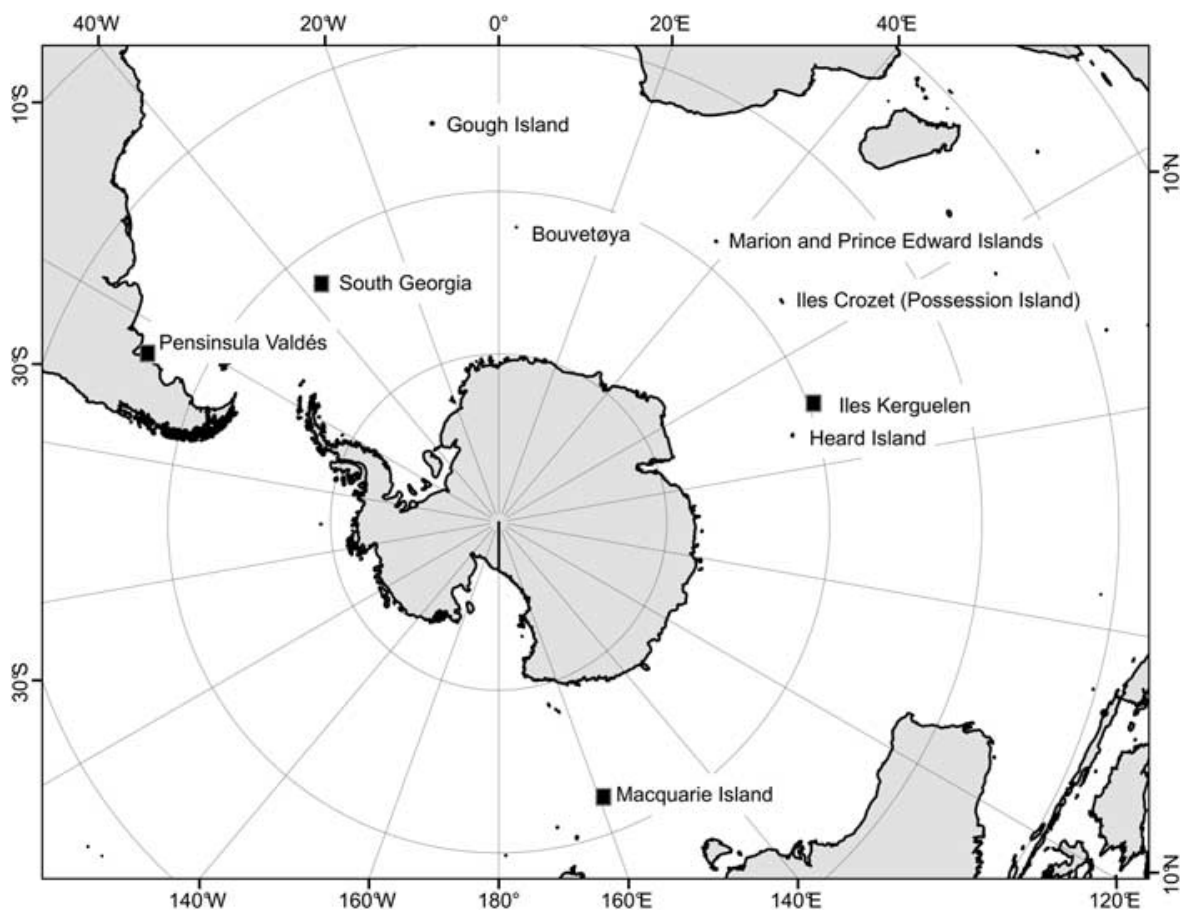

Fig. 1. The four major populations of southern elephant seals in each geographical province (squares) and locations of sub-populations of southern elephant seals within the southern Atlantic and Indian oceans mentioned in the text. seals migrate to foraging areas that may be more than $3000 \mathrm{~km}$ from the previous haulout site (e.g. Bailleul et al. 2007, Tosh 2010). Despite the long-range migrations, most elephant seals are philopatric and return to their natal island to breed and moult (Nicholls 1970, Lewis et al. 1996). This high site fidelity results in limited exchange of breeding individuals between major populations and four genetically distinct provinces or populations are recognized: the South Georgia province in the southern Atlantic Ocean, the Macquarie province in the southern Pacific Ocean, the Kerguelen province in the southern Indian Ocean, and the Peninsula Valdés population on the Argentinean coast in the southern Atlantic Ocean (the only continental breeding population) (Fig. 1, Hoelzel et al. 2001, McMahon et al. 2005a). Although movement of individuals between these provinces occur infrequently (Fabiani et al. 2003, Reisinger \& Bester 2010), movement between sub-populations within a province may be more frequent and an equally important population process, especially for small populations.

Within the Kerguelen province, two large principal elephant seal populations are found at Iles Kerguelen and Heard Island, together with smaller sub-populations at Iles Crozet and the Prince Edward Islands (Marion Island and Prince Edward Island, Fig. 1) (McMahon et al. 2005a). A long-term markresight programme at Marion Island (MI) and intermittent elephant seal research at Heard Island (HI), Iles Kerguelen (IK) and Iles Crozet (IC) have indicated some inter-island movement between $\mathrm{MI}$ and other sub-populations within this province (Bester 1989 and references therein, Guinet et al. 1992). Sightings of individuals marked with plastic flipper tags suggest that, in relation to MI, movement between MI and IC occurs most frequently within this province, that movements are migratory and that it mainly involves juvenile seals (Bester 1989). Dispersal between MI and other islands seems rare: from 1973 to 1986, a single breeding female from IC dispersed to MI (Bester 1989), while two MI females bred at IC in 1988 and 1989 respectively (Guinet et al. 1992).

This paper aims to improve understanding of inter-island movement between MI and other islands within the Kerguelen province. Marking of elephant seals at IC along with concurrent resights of tagged seals at MI allow assessment of dispersal and dispersion of tagged southern elephant seals from IC to MI. We use tag resight data collected at MI from 1987-2009 to address the following aims, specifically for seals originating from IC:

1. To what extent are dispersion and/or dispersal occurring?

2. Can dispersal be described as natal or breeding dispersal and is gene flow occurring?

3. Are there temporal, haulout type, sex or age class differences in dispersion/dispersal?

4. Are IC seals transient visitors to MI (occur only once) rather than potential immigrants to the population (repeatedly sighted)?

The modest marking and resight effort at localities other than at MI within the Kerguelen province during this study period curbs quantitative assessment of inter-island movement; however, evidence of such movements between IK and MI are presented. In addition to tag resight data, we provide data of inter-island movement using satellite telemetry. 


\section{Methods}

Study area

Marion Island (MI; $300 \mathrm{~km}^{2}$ ) and Prince Edward Island (PEI; $46 \mathrm{~km}^{2}, 19 \mathrm{~km}$ north-east of MI) form the Prince Edward Islands (PEIs) archipelago. The nearest landmass to the PEIs is the five constituent islands of Iles Crozet (IC), c. $1000 \mathrm{~km}$ to the east. Elephant seal research is largely restricted to MI and Ile de la Possession (Possession Island, PI; $150 \mathrm{~km}^{2}$, $1140 \mathrm{~km}$ from MI) at the PEIs and IC respectively. Iles Kerguelen (IK) and Heard Island (HI) are $2640 \mathrm{~km}$ and $2740 \mathrm{~km}$ to the east of the PEIs, respectively (Fig. 1).

\section{Marion Island (MI)}

Nearly all weaned elephant seal pups born at MI from 1983-2008 were sexed and double tagged with uniquely numbered, colour-coded plastic Dal 008 Jumbo-rototags ${ }^{\circledR}$ (Dalton Supplies Ltd, Henley-on-Thames, UK) in an ongoing mark-recapture study (Bester 1988, de Bruyn et al. 2008). During this time, resights of elephant seals were made on a 7 - or 10-day cycle at all beaches along a $51.9 \mathrm{~km}$ coastline where southern elephant seals regularly haulout. Once a month, beaches on the western side of the island (where seals rarely haulout) were checked for the presence of seals. No censuses were conducted during the winter (mid-May to mid-August) of 1987 and 1988.

For every tagged seal that was resighted at MI (including PI tags), the date and locality of the sighting, tag colour combination and tag number were recorded to identify the seal, along with information about the age class, sex (if identified) and social status (breeding status, moult stage or winter haulout). Seals were grouped into the following age class categories: under-yearling ( $<1$ year), yearling ( 1 to $<2$ year), subadult ( 2 to $<4$ (females); 2 to $<6$ (males)), adult female ( $>4$ (or $>3$ if giving birth at age 3 )), adult male ( $>6$ year). Collectively, under-yearling, yearling and subadult age classes are referred to as "juveniles". During the breeding season, the social status indicated whether male seals were "beachmasters" (males in exclusive control of a harem) or "bachelors" (subordinate males at the periphery of harems and not challenging the beachmaster) and whether or not a female has given birth to a pup. "Assistant beachmasters" and "challenger bulls" are uncommon at Marion Island due to the small size of harems. Possession Island tag resight records were authenticated against the original tagging records to confirm the natal island, year of birth and sex (if recorded at tagging).

From 1999-2008, 132 satellite-relay data loggers (SRDLs) were deployed at MI (Tosh 2010), including deployment of SRDLs on male and female seals from nearly all age classes and pelagic phases following all haulout types (winter, post-moult, post-breeding). Devices were mostly deployed on MI tagged individuals $(n=108)$, however, in April $1999(n=8)$, April $2002(n=9)$, April $2004(n=4)$
Table I. Numbers of southern elephant seals tagged from 1984-91 at Possession Island, Iles Crozet and numbers of individuals belonging to each cohort resighted at Marion Island from 1987-2002. The percentage of marked PI seals resighted at MI is given for cohorts 1986-91.

Resights at Marion Island from the 1984 and 1985 cohorts is biased low as observations for this study only commenced in 1987 .

\begin{tabular}{lccc}
\hline Year (cohort) & Single tagged & Double tagged & $\begin{array}{c}\text { Resighted at MI } \\
(1987-2002)\end{array}$ \\
\hline 1984 & 346 & 18 & 1 \\
1985 & 336 & 145 & 25 \\
1986 & 1 & 285 & $15(5.3 \%)$ \\
1987 & & 324 & $21(6.5 \%)$ \\
1988 & & 234 & $20(8.5 \%)$ \\
1989 & & 247 & $40(16.2 \%)$ \\
1990 & & 200 & $56(28 \%)$ \\
1991 & 196 & $21(10.7 \%)$ \\
\hline
\end{tabular}

and April $2005(n=3)$ SRDLs were deployed on unmarked/ untagged (and presumably non-natal) seals hauled out at MI. From 2006-08, the probability of device recovery was improved by selecting tagged individuals that had regularly returned to MI during previous breeding and moult haulouts.

\section{Iles Crozet (IC)-Possession Island (PI)}

Recently weaned elephant seal pups were marked at PI from 1984-91. Seals were either single or double tagged with Jumbo-rototags ${ }^{\circledR}$ (Dalton Supplies Ltd) (Table I). Every year during the peak breeding season, from 1980-97, a total island census was done at PI (Guinet et al. 1992); however, no tag resight data is available. As such, movement of MI seals to PI and migrations of PI seals (from PI to MI and back to PI) could not be assessed (e.g. Van den Hoff 2001).

\section{Iles Kerguelen (IK)}

Large numbers of elephant seal pups $(n=13818)$ were tagged between 1970 and 1979 at IK (Lenglart \& Bester 1982). Resight effort at MI was low during, and for the four subsequent years to the end of the IK marking period. In 2006, 200 weaned pups were tagged on the Courbet Peninsula.

\section{Analyses}

Encounter history profiles were constructed for each of the PI seals resighted at MI. Multiple resights of the same tagged individual during any single haulout period were reduced to one encounter event (the first sighting of the seal). Sightings of the same tagged individual in different haulout periods were considered as separate encounters of that individual. Seal age was estimated by subtracting the birth date (taken as 15 October every year (the peak haulout date for breeding females at PI; Guinet et al. 1992)) from the resight date. 


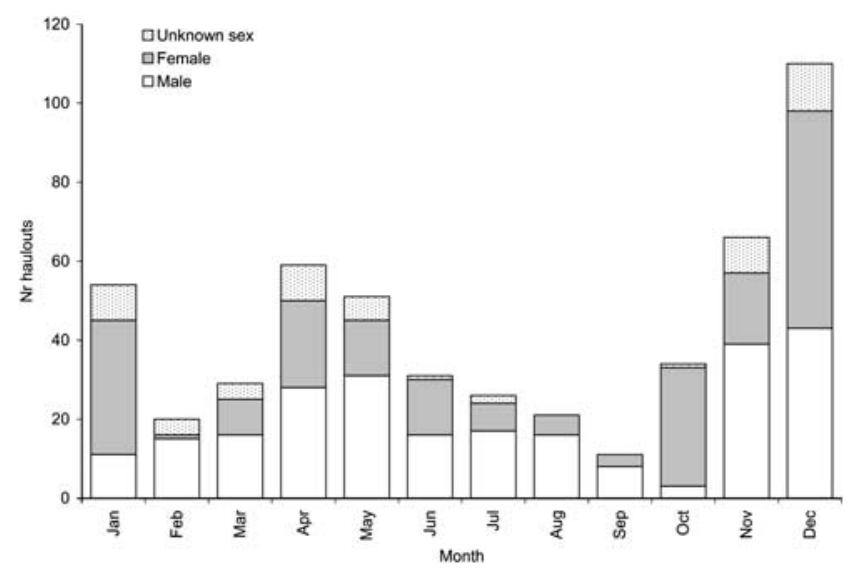

Fig. 2. Cumulative monthly distribution (1987-2002) of numbers of southern elephant seals from Possession Island (PI) hauling out at Marion Island (MI). Only the first observation of an individual $(n=199)$ during every haulout $(n=512)$ is included.

Pearson's chi-square goodness of fit test (with significance set as $P<0.05$ ) was used to establish whether the frequency distribution of PI seals that haulout at MI differs from the expected distribution in relation to sex and time (monthly variation). For age, the observed age frequency distribution of PI seals hauling out at MI was plotted. Additionally, the age frequency distribution was expressed as the proportion $P$, calculated as the number of individuals observed per age class divided by the number of individuals predicted to be alive based on the population age structure, assuming that PI seals survive at similar rates to MI seals (de Bruyn 2009).

The encounter history profiles of PI seals breeding at Marion Island were scrutinized to determine the age of first breeding at MI and to establish whether breeding haulouts were preceded by non-breeding haulouts. The return rate of seals (whether or not seals returned for subsequent haulouts following their first haulout) was related to the age at which the first haulout at MI was made and tested for departure of expected frequency distribution (equal return rates for all ages) using Pearson's chi-square test.

The proportion of tagged seals moving between PI and MI was calculated separately for birth cohorts 1986-91, based on numbers of seals tagged and resighted at the respective localities and not accounting for tag-loss or survival. Juvenile haulout encounters for the 1984 and 1985 birth cohorts predated this study (these were reported by Bester 1989) and therefore these cohorts were not included in this analysis.

For the satellite telemetry data, at-sea locations were filtered according to a $10 \mathrm{~km} \mathrm{~h}^{-1}$ velocity algorithm to remove positions that required unrealistic travel distances per unit time (McConnell et al. 1992). Location positions were subsequently averaged to a daily location to provide regular trajectories over time and mapped in ArcMap (ArcGIS) (see Tosh 2010 for details). We extracted all tracks where seals

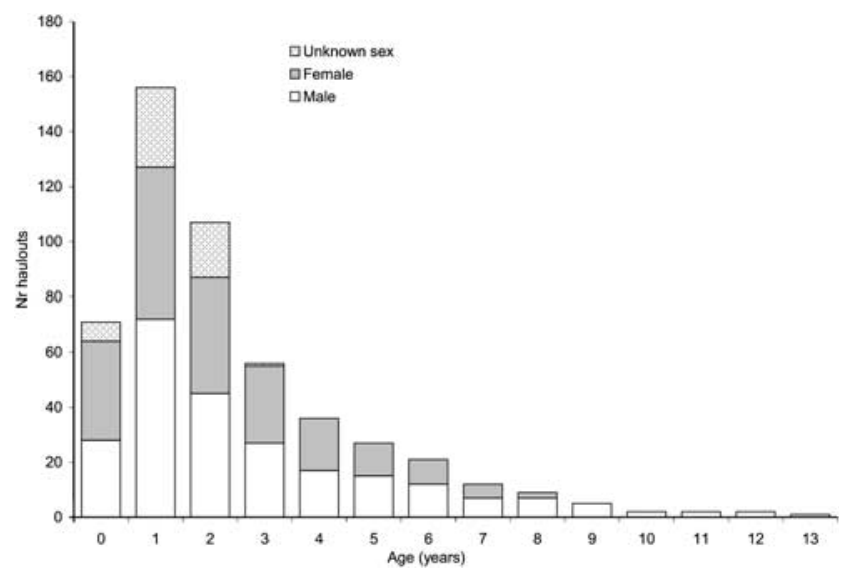

Fig. 3. Age frequency distribution of southern elephant seals from Possession Island (PI) hauling out at Marion Island (MI). Age signifies the initial age, e.g. age 0 is equivalent to 0 to 364 days. Only the first observation of an individual $(n=196)$ during every haulout $(n=507)$ is included.

hauled out at locations other than MI or PEI and discuss these qualitatively without attempting a rigorous analysis.

\section{Results}

PI tag resights at MI

From 1987-2002, 199 PI individuals were sighted 1237 times during 512 separate haulout periods at MI. Seals

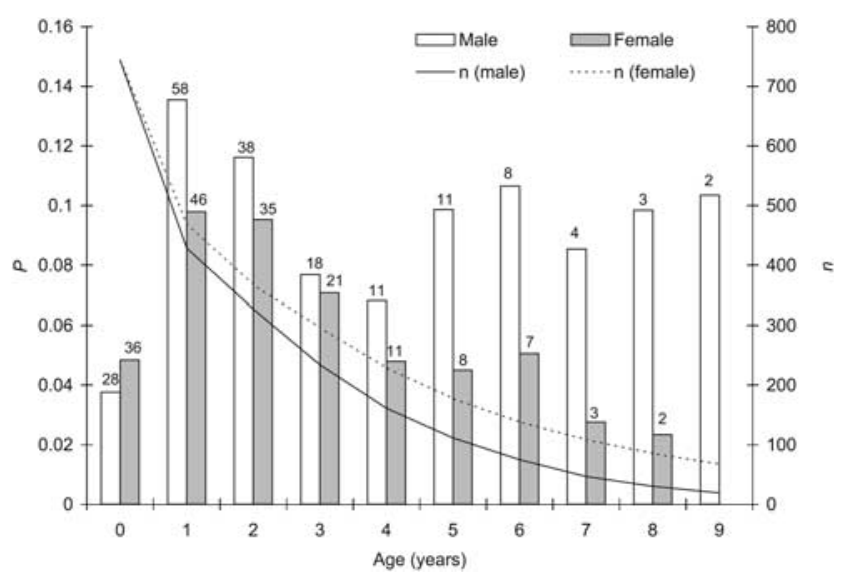

Fig. 4. Age frequency distribution (age 0-10) of southern elephant seals from Possession Island (PI) hauling out at Marion Island (MI) expressed relative to the number of seals surviving (population age structure). The barplot represents the proportion $P$ (the number of individuals observed per age divided by the number of marked individuals predicted to be alive from the population age structure). The sample size (number of seals observed per age class) is given for every age. The population age structure (secondary y-axis) is given by two lines for males and females respectively. Age signifies the initial age, e.g. age 0 is equivalent to $0-364$ days. 
were present during 222 autumn/winter, 241 moult and 49 breeding haulouts. Seven of these seals were also seen at MI prior to 1987 (reported in Bester 1989) whereas no PI tagged seals were resighted from April 2002 to present. Seals occurred throughout the year but numbers of PI seals resighted per month fluctuated significantly $\left(X^{2}=193.06\right.$, $\mathrm{df}=11, P<0.01, n=512)$ in relation to the annual haulout cycle of southern elephant seals. Resights peaked during the moult (November-January) when $45 \%$ of all haulouts of PI tagged elephant seals occurred, and during the autumn/ winter mid-year haulout (April-May) (Fig. 2). Similar numbers of male and female seals could be identified (78 males, 80 females, 41 unidentified; $X^{2}=0.03, \mathrm{df}=1$, $P=0.87$ ). The observed age frequency distribution of PI seals resighted at MI was strongly juvenile biased and collectively, seals aged 1 and 2 accounted for $52 \%$ of all PI seal haulout occasions at MI (Fig. 3). Possession Island under-yearlings hauled out at MI from as young as 4 months of age and under-yearlings accounted for $14.1 \%$ of all resights. The oldest females recorded were aged $8(n=2)$, with the tail of the age frequency distribution attributed to three males reaching ages of 9,10 and 13 respectively. Although juvenile seals occurred in the highest numbers, only females exhibited the same trend when numbers were expressed relative to the population age structure and as a proportion of the individuals still alive (Fig. 4). Although absolute numbers of males observed at MI decreased with age as mortality cumulated, adult males occurred at comparatively higher proportions when numbers observed were expressed relative to the proportion of individuals still alive (Fig. 4).

\section{Natal or breeding dispersal}

From 1989-98, at least 18 PI females were found present 33 times during breeding seasons at MI, with pupping confirmed in 27 of these cases. Adult males $(n=6)$ were present on 16 occasions during breeding seasons from 1989-2001, and three males successfully gained 'beachmaster' status in 11 instances. One PI male controlled harems for six consecutive breeding seasons (1996-2001). During this period, 196 females, or $7.6 \%$ of all females breeding at MI at the time, were present/passed through harems under his control.

PI seals breeding at MI were nearly always seen at MI prior to their first breeding haulout. Only two PI females were seen breeding at age 4 , without being observed at MI previously. All of the seals seen prior to breeding, moulted at least once at MI. Eleven moulted at MI for the first time at age 1 , eight at age 2 , and one at age 3 . With the inclusion of winter haulouts, these seals hauled out at MI as juveniles for the first time at age $1.21 \pm 0.60$ years (mean $\pm \mathrm{SD}$ ) at an average of $5.05( \pm 4.09)$ times prior to breeding. Females were observed to breed for the first time at MI at age 3 $(n=7)$, age $4(n=6)$, age $5(n=2)$ and age $6(n=3)$, with the mean age of first (observed) breeding equaling 4.05

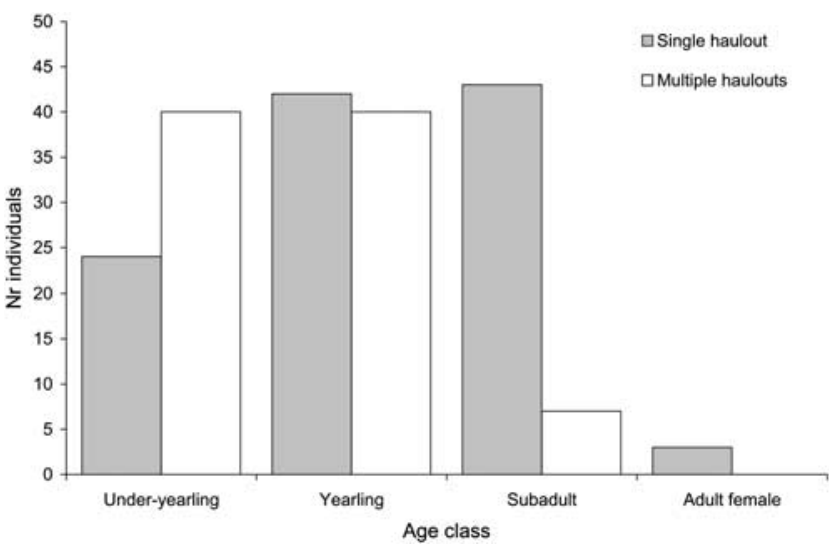

Fig. 5. The return rate (single or multiple haulouts) of Possession Island southern elephant seals $(n=196)$ following their first haulout at Marion Island (MI). The $\mathrm{x}$-axis indicates the age class when the first haulout by an individual was made at MI (i.e. every individual contributes only one data point, to the youngest age class possible). Seals that haulout at MI for the first time as under-yearlings are likely to return to MI for subsequent (multiple) haulouts. Seals that haulout at MI for the first time as subadults or adult females have lower return rates. None of the marked PI seals hauled out at Marion Island for the first time as an adult male.

years. Males participated in the breeding season for the first time at age $6(n=1)$, age $7(n=2)$ and age $8(n=2)$.

\section{Transient and immigrant movement}

The return rate of seals following their first haulout was significantly influenced by the age of the seal at the first haulout $\left(X^{2}=27.85, \mathrm{df}=2, P<0.01, n=196\right)$. More than half $(56 \%)$ of the PI seals seen at MI were observed during only one haulout $(n=112)$; these were predominantly yearlings $(n=42)$ and subadults $(n=43)$ at the time of the haulout. Seals hauling out for the first time as yearlings showed equal likelihood of returning or not returning for a second haulout $(48 \%, n=82)$, whereas seals hauling out at MI for the first time as subadults $(14 \%, n=50)$ or adults $(<1 \%, n=3)$ were commonly not recorded again (Fig. 5). In contrast, $62.5 \%$ of PI seals which first hauled out at MI as under-yearlings $(n=64)$ returned to MI for subsequent haulouts (Fig. 5).

\section{Proportion of PI tagged seals at MI}

From 1986-91 nearly 1500 seals were tagged at PI; 173 , or $11.63 \%$ of these were resighted at MI (Table I). Overall resight rates ranged from $5.2 \%$ to $28 \%$ for different birth cohorts, the lowest resight rates corresponding to birth cohorts 1986 and 1987 (Table I). The elephant seal population at PI remained stable between 1990 and 1997, at $553 \pm 32$ breeding females (mean $\pm \mathrm{SD}$ ) (Guinet et al. 1999 ) and if $11.63 \%$ of pups born to these females were to 

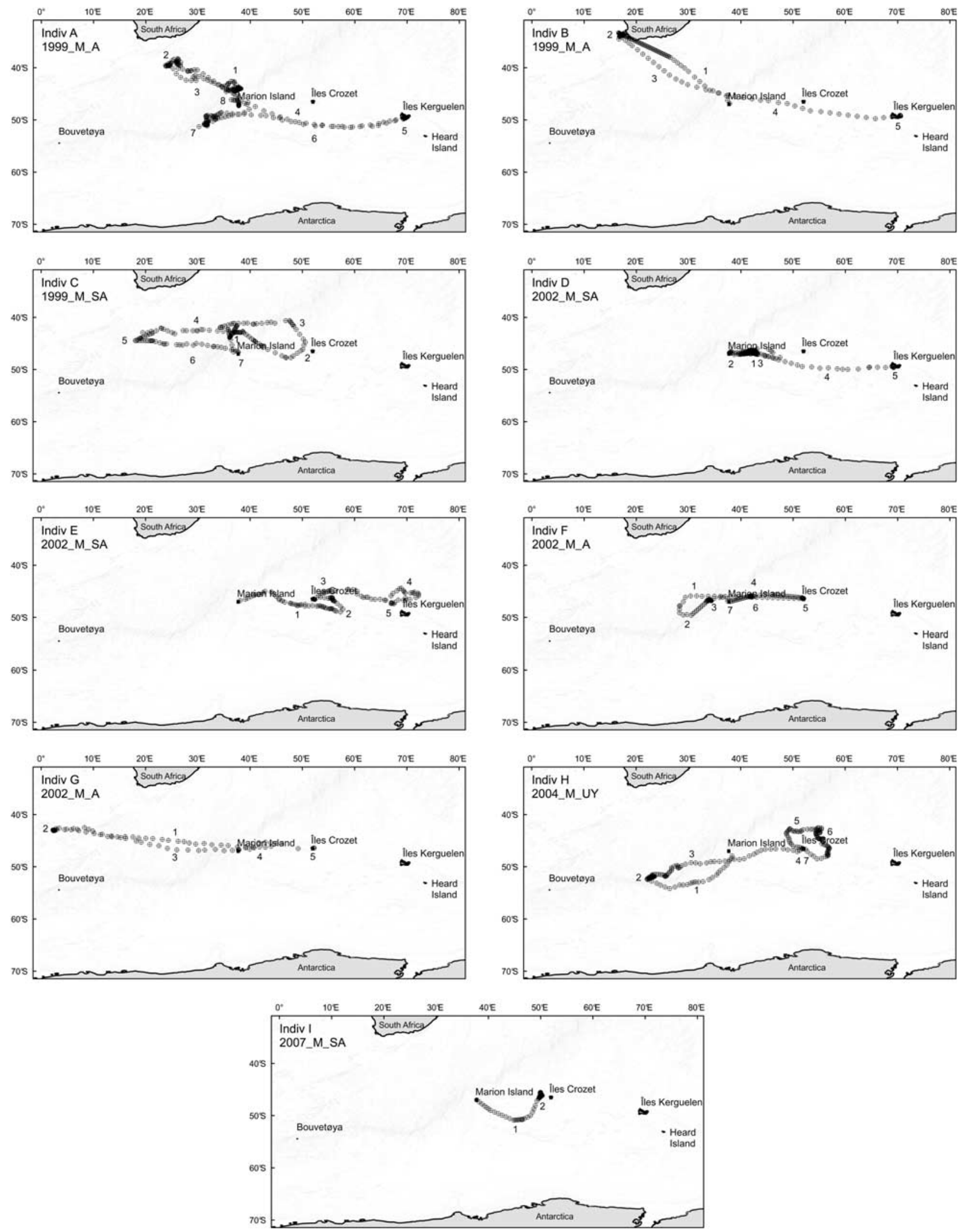
Table II. Summary data of southern elephant seals (all males) fitted with satellite relay data loggers (SRDLs) at Marion Island (MI) that subsequently hauled out at Iles Kerguelen (IK) or Iles Crozet (IC). 'Tag no' refers to Marion Island flipper-tags; 'Haulout type' refers to the haulout phase at either IK or IC; and 'Return to MI' indicates whether the seal was tracked back to MI following the haulout event at IK or IC. All seals were initially tracked during the austral winter (following a mid-year haulout at MI). Two post-breeding tracks of adult males (A and F) were also recorded during the summer.

\begin{tabular}{|c|c|c|c|c|c|c|c|}
\hline Seal ID & Age class ${ }^{1}$ & Tag no & Departure from MI & Foreign haulout locality & Haulout type & Return to MI & Last SRDL transmission \\
\hline A & $\mathrm{AM}$ & & Apr 1999 & IK - Gallieni Peninsula & Breeding & Yes (moult) & Mar 2000 \\
\hline B & AM & & Apr 1999 & IK - Courbet Peninsula & Breeding & Fail & Nov 1999 \\
\hline $\mathrm{C}$ & $\mathrm{SA}$ & & Apr 1999 & IC - Ile aux Cochons & Winter & Yes (moult) & Nov 1999 \\
\hline $\mathrm{D}$ & SA & & May 2002 & IK - Gallieni Peninsula & Moult & Fail* & Dec 2002 \\
\hline $\mathrm{E}$ & SA & & Apr 2002 & IC - Ile de l'Est & Winter & Fail & Sep 2002 \\
\hline $\mathrm{F}$ & AM & & May 2002 & IC - Possession Island & Breeding & Yes (moult) & Jan 2003 \\
\hline G & $\mathrm{AM}$ & & Apr 2002 & IC - Ile de l'Est & Breeding & Fail & Oct 2002 \\
\hline $\mathrm{H}$ & UY & YY232 & Apr 2004 & IC - Possession Island & Winter & Yes (moult) & Nov 2004 \\
\hline I & $\mathrm{SA}$ & BB116 & Apr 2007 & IC - Ile aux Cochons & Winter & Yes (winter) & Oct 2007 \\
\hline
\end{tabular}

${ }^{1} \mathrm{AM}=$ adult male, $\mathrm{SA}=$ subadult, $\mathrm{UY}=$ under-yearling

*Returned for a winter haulout at MI prior to moult haulout at IK

\# Probably moulted at IC in 2007, returned to MI in Apr 2008 (identified by flipper-tags)

migrate to MI, some 64 seals from each birth cohort would haulout at MI at some stage. The proportion of seals migrating to MI may be as high as $21.45 \%$ or 119 individuals per cohort (upper 95\% confidence interval calculated from cohort resight rates between 1986 and 1991, $n=6$ ).

\section{Other tag resights at MI}

In 2006, 200 weaned pups were tagged at Iles Kerguelen (IK). One of these was resighted at MI as an under-yearling in August 2007, but not thereafter.

\section{Satellite telemetry}

In total, nine seals tracked from MI hauled out at IK $(n=3)$ or IC $(n=6)$ (Fig. 6). Seven out of 24 SRDL deployments on untagged seals $(29 \%)$ recorded haulout events at either IK or IC whereas two out of 108 MI-tagged seals fitted with SRDLs hauled out at IC (Table II).

\section{Discussion}

Movement, migration and especially breeding dispersal are key processes in any study of population biology (Clobert et al. 2001). For southern elephant seals, intra-island and local archipelago movements (Hofmeyr 2000, Setsaas et al. 2008, Oosthuizen et al. 2009) and long range inter-island movements (Bester 1988, 1989, Guinet et al. 1992, Hindell \& McMahon 2000, Van den Hoff 2001, Van den Hoff et al. 2003, Lewis et al. 2006, Reisinger \& Bester 2010) have been documented through resights of marked individuals. To provide robust quantitative estimates of movement rates, this method relies on large numbers of tagged subjects and an intensive resighting regime over large temporal and spatial scales. Recovery rates are often low when research programmes are not temporally aligned, leading to inadequate data for distant unobservable sites. Satellite telemetry, apart from providing insight to the pelagic foraging behaviour of elephant seals, may additionally provide evidence of inter-island movement. Although often dealing with small sample sizes, tracking the at-sea movements of elephant seals from MI (this study) confirmed movement of seals between the MI, IC and IK populations. Recent non-random selection of individuals (favouring those that regularly return) excludes the use of all the tracking data to quantify dispersal rates from MI, but earlier random deployments suggest that these rates are low for seals native to MI. Our results support previous indirect measures (genetic approaches) of dispersal, suggesting it is male biased, but there is also female dispersal between MI and HI (Chauke 2008). While no comparisons have been made with IC and IK populations due to the lack of population genetic data, gene flow between these populations within the Kerguelen province is plausible (this study, Chauke 2008).

This study confirms MI as an important winter resting and moult haulout site for juvenile seals from IC, with up to $28 \%$ of pups tagged in a birth cohort hauling out at MI. Our estimates based on resights of tagged seals represent minimum dispersal rates, with actual dispersal rates probably somewhat higher due to imperfect detection and tag-loss. Resight rates for the 1986 and 1987 PI cohorts are visibly biased low as no tag resights were made at MI during the

Fig. 6. (opposite) Movement tracks of southern elephant seals $(n=9)$ fitted with SRDL devices at Marion Island and migrating to either Iles Crozet or Iles Kerguelen. The upper left corner of each box contains the following information: the individual track identity (e.g. ind. A), the year of deployment, sex $(\mathrm{M}=$ male) and age class $(\mathrm{UY}=$ under-yearling, $\mathrm{SA}=$ subadult, $\mathrm{A}=$ adult). Numbers alongside the track indicate the route a seal followed. A concentration of points on the track (darker areas) represents areas of restricted movement that usually corresponds to foraging areas. 
winters of 1987 and 1988. Additionally, numbers were not corrected for tag-loss and although tag-loss may be low for juveniles (Oosthuizen et al. 2010), higher tag-loss among adult age classes and especially males may have decreased the number of adult male seals resighted, compared to females. Seals marked with a single tag (e.g. 1984 and 1985 PI cohorts) are also expected to become unidentifiable more rapidly, lowering resighting rates. Apart from PI, no data exists for the other four constituent islands of IC where unknown numbers of elephant seals breed. Elephant seals from these islands are expected to haulout at MI at similar rates to that of PI seals.

The abundance of IC seals at MI suggests that elephant seals from PI may be foraging to the west of IC, encountering MI during their foraging migrations. Marion Island elephant seals generally forage to the west of MI (Tosh 2010), but the extent of foraging area overlap between individuals of the two sub-populations (Bradshaw et al. 2002), and whether seals from these two subpopulations compete for the same, possibly limiting food resource (Pistorius et al. 1999, McMahon et al. 2003), is unknown. At an ecosystem level, migrant and immigrant IC seals will add nutrients to the MI terrestrial ecosystem via excreta and moulted skin (Smith 2008). Migrant and immigrant seals may also fall prey to the killer whale (Orcinus orca (L.)) population at MI which take elephant seals (Condy et al. 1978) and are most abundant during the summer (October-December, Keith et al. 2001) following the elephant seal breeding season and at a time when juvenile elephant seals haulout to moult.

Despite the relatively large numbers of elephant seals dispersing to MI during the winter and for the moult, breeding dispersal is less common. However, both sexes recruit to the MI breeding population. Dispersal in mammals (Greenwood 1980) including marine mammals (e.g. Möller \& Beheregaray 2004, Herreman et al. 2009) is generally male biased. Due to the extreme polygynous mating system, elephant seal males are predicted to be the dispersing sex (Greenwood 1980) and greater male dispersal has been indicated by both genetic (Slade et al. 1998, Hoelzel et al. 2001, Fabiani et al. 2003) and markrecapture studies (e.g. Van den Hoff 2001, Lewis et al. 2006) of elephant seals, although long-range female migrations may occur (e.g. Hindell \& McMahon 2000). This study recorded more individual dispersing breeding females than males; however, greater male-mediated gene flow would ultimately have been attained due to the polygynous mating system and one or two extremely successful immigrant males. A single successful dispersal event by a male may, therefore, have correspondingly large effects on population genetics. Elephant seal males have higher pre-breeding mortality than females due to higher mortality rates and delayed sexual and social maturity (age 6, compared to age 3-4 for females at MI). Consequently, although absolute numbers of immigrant breeding males may be lower than that of females, when viewed against the population age structure, the proportion of dispersing males is actually higher than that of females. Caution should be exercised, however, when interpreting proportions calculated from few surviving individuals in older age classes. Most immigrant breeders hauled out repeatedly at MI prior to breeding, often as under-yearlings for the first time. The mean age of first breeding (primiparity) for MI females is 3.95 years (McMahon et al. 2003) and the mean age of first (observed) breeding of PI females at MI was 4.05 years. Seven PI females breeding at MI were definite first time breeders (age 3). Even though breeding probabilities of age 3 females are relatively low (Pistorius et al. 2001), we cannot say with certainty that females older than age 3 had not bred previously. Still, with the observed age of first breeding of PI females at MI approaching mean primiparity of MI females, dispersal can be best described as 'natal dispersal'.

Although PEI and IC are the closest islands to MI, these localities have relatively small elephant seal populations and the large populations at IK and HI, although more distant, may significantly contribute immigrant seals to MI. Over the last two decades, pup production at the Courbet Peninsula, IK has been stable at around 40000 individuals (Authier et al. 2011) and c. 18000 pups are born per annum at HI (Slip \& Burton 1999). Even if emigration rates are low $(<1 \%)$, many unmarked seals from these localities may arrive at MI. From 2004-09, SRDLs were deployed on 110 juvenile, adult female and adult male elephant seals at IK. None were observed to haulout on IC, MI or PEI (C. Guinet, unpublished data), although one breeding female travelled to the vicinity of IC and MI (see Fig. 3 (A), ind. no. 5 in Bailleul et al. 2007). From our small sample of tracked, unmarked (untagged) males that hauled out at MI during autumn (April), two were tracked to IK where they hauled out for the breeding season. Because these seals were untagged, the satellite track to IK probably represents the return leg of the migration to the natal site for the breeding season. One male was tracked back to MI for the subsequent moult haulout, and it is probable that such dispersion may occur more frequently. Seals that disperse from the natal island for non-breeding purposes only may be faithful to that behaviour throughout their lives, possibly because long-term fidelity to particular foraging regions has some advantages for lifetime foraging success (Bradshaw et al. 2004). The large distances between populations within the Kerguelen province is no barrier for any sex or age class as elephant seal under-yearlings are already capable of moving such distances. Because immigration into a distant population appears to be more likely if seals haulout at the locality early on in life (this study), this capability increases the chances that migratory individuals may relocate permanently between these populations.

Population exchange has important consequences for population demographics and dispersal may mediate the genetic and ecological factors regulating closed populations (Ferriere et al. 2000). With little evidence suggesting 
significant dispersal between MI and other island populations, together with the difficulty of incorporating quantitative dispersal figures into demographic models, dispersal was hitherto often assumed to be negligible (e.g. Pistorius et al. 1999, 2004, McMahon et al. 2009). Even so, earlier population modelling showed that immigration of as few as eight female elephant seals (aged 1-4) per year to MI has a dramatic effect on the predicted future population size (McMahon et al. 2005b) and it is evident that dispersal should be considered when assessing vital rates for this and other southern elephant seal populations in the southern Indian Ocean. A metapopulation model, rather than discreet population models, may better describe southern Indian Ocean southern elephant seal populations as a whole. Southern Indian Ocean southern elephant seal sub-populations (after Bradshaw et al. 2002) meet some of the specific criteria of classical metapopulation theory (Hanski 1999) and as recommended by Elmhagen \& Angerbjörn (2001) for large mammals, including: 1) discrete local breeding populations, 2) dispersal between local populations (this study), 3) demographic asynchrony among local populations (dissimilar growth rates, e.g. decreasing and stable populations, McMahon et al. 2005a, although broadscale linkage in population growth rates (demography) are plausable), and 4) risk of extinction (McMahon et al. 2005b).

\section{Future research}

This study incorporated data from two temporally overlapping tagging regimes. Currently, MI is the only island in the southern Indian Ocean where elephant seals are tagged annually and resighted at regular intervals. Accordingly, a new marking protocol was recently initiated at MI aiming to address some of the unanswered questions regarding dispersal and dispersion between MI and other islands. Untagged seals hauling out at MI during winter as under-yearlings and during the moult (age 1) are tagged with uniquely identifiable tags to mark them as "non-native seals". This approach is possible as virtually all MI born seals are tagged every year (de Bruyn et al. 2008), and tag-loss from weaning to age 1 is negligible (Oosthuizen et al. 2010). This marking protocol aims to further quantify dispersal and dispersion involving the MI population, even if the source populations of these seals remain unknown. Assessment of gene flow between populations in the southern Indian Ocean will complement the current study and previous genetic studies (Chauke 2008), while insight to the foraging distribution of elephant seals from IC will complement at-sea distribution data for seals from the MI and IK populations.

The extent of emigration of seals from MI remains unclear. Because the majority of MI seals forage to the west and south-west of MI (Tosh 2010) where the closest elephant seal population is on Bouvetøya (c. $2500 \mathrm{~km}$ distant), we hypothesize that the degree of immigration to MI from IC and IK to the east overshadows emigration from MI. Although several SRDL females from MI travelled to the immediate vicinity of Bouvetøya during their pelagic migration, none has hauled out there. Also, no MI tagged seals have been observed at Bouvetøya during the moulting periods in five expeditions there over the course of $\sim 15$ years (Kirkman et al. 2001). Yet, MI tagged elephant seals resighted at Gough Island, South Atlantic Ocean, (Reisinger \& Bester 2010) and IC (Bester 1989) to the west and east of MI respectively, suggest some emigration, although some of these movements may be migratory. Furthermore, local dispersal and dispersion (temporary or permanent) to neighbouring PEI occurs at low but apparently consistent levels (Oosthuizen et al. 2009).

\section{Acknowledgements}

We thank field personnel of the Marion Island, Iles Crozet and Iles Kerguelen southern elephant seal research programmes who assisted in collecting data on elephant seals at these localities. Logistical support and research permits for Marion Island were provided by the South African Department of Environmental Affairs within the South African National Antarctic Program (SANAP). The Department of Science and Technology, through the National Research Foundation (NRF), provided financial support. WCO received financial support from a NRF Grantholder-linked bursary within the project "Conservation of Seabirds, Shorebirds and Seals" led by L. Underhill of the Animal Demography Unit, Department of Zoology, University of Cape Town. Our colleagues from the Australian Antarctic Division (H. Burton and J. van den Hoff), the Alfred Wegener Institute for Polar and Marine and Marine Research (Drs J. Plötz, H. Bornemann and S. Ramdohr) and the Hubbs-Sea World Research Institute (Dr B.S. Stewart) contributed SLDRs and funded ARGOS satellite time in support of the SANAP project entitled 'Southern Elephant Seals as Oceanographic Platforms'. We use some basic tracking results here in support of the markrecapture data used in this manuscript. I.C. Field, R.R. Reisinger and two reviewers provided helpful comments. The project has ethics clearance from the Animal Use and Care Committee (AUCC 040827-024) of the Faculty of Veterinary Science, University of Pretoria.

\section{References}

Authier, M., Delord, K. \& Guinet, C. 2011. Population trends of female elephant seals breeding on the Courbet Peninsula, Iles Kerguelen. Polar Biology, 34, 319-328.

Bailleul, F., Charrassin, J.-B., Ezraty, R., Girard-Ardhuin, F., McMahon, C.R., Field, I.C. \& Guinet, C. 2007. Southern elephant seals from Kerguelen Islands confronted by Antarctic sea ice: changes in movements and in diving behaviour. Deep-Sea Research II, 54, 343-355.

BESTER, M.N. 1988. Marking and monitoring studies of the Kerguelen stock of southern elephant seals Mirounga leonina and their bearing on biological research in the Vestfold Hills. Hydrobiologia, 165, 269-277. 
Bester, M.N. 1989. Movements of southern elephant seals and subantarctic fur seals in relation to Marion Island. Marine Mammal Science, 5, 257-265.

Bradshaw, C.J.A., Hindell, M.A., Sumner, M.D. \& Michael, K.J. 2004. Loyalty pays: potential life history consequences of fidelity to marine foraging regions by southern elephant seals. Animal Behaviour, 68, $1349-1360$.

Bradshaw, C.J.A., McMahon, C.R., Hindell, M.A., Pistorius, P.A. \& BESTER, M.N. 2002. Do southern elephant seals show density dependence in fecundity? Polar Biology, 25, 650-655.

CHAUKE, L.F. 2008. Genetic variation and population structure of southern elephant seals Mirounga leonina from Marion Island. MSc dissertation, University of Pretoria, 93 pp. [Unpublished.]

Clobert, J., Danchin, E., Dhondt, A.A. \& Nichols, J.D. 2001. Dispersal. New York: Oxford University Press, 480 pp.

Condy, P.R., van Aarde, R.J. \& Bester, M.N. 1978. The seasonal occurrence and behaviour of killer whales Orcinus orca, at Marion Island. Journal of Zoology, 184, 449-464.

DE BRUYN, P.J.N. 2009. Life history studies of the southern elephant seal population at Marion Island. $\mathrm{PhD}$ thesis, University of Pretoria, $196 \mathrm{pp}$. [Unpublished.]

de Bruyn, P.J.N., Tosh, C.A., Oosthuizen, W.C., Phalanndwa, M.V. \& BESTER, M.N. 2008. Temporary marking of unweaned southern elephant seal (Mirounga leonina L.) pups. South African Journal of Wildlife Research, 38, 133-137.

Elmhagen, B. \& Angerbjörn, A. 2001. The applicability of metapopulation theory to large mammals. Oikos, 94, 89-100.

Fabiani, A., Hoelzel, A.R., Galimberti, F. \& Muelbert, M.M.C. 2003. Long-range paternal gene flow in the southern elephant seal. Science, 299, 676.

Ferriere, R., Belthoff, J.R., Olivieri, I. \& Krackow, S. 2000. Evolving dispersal: where to go next? Trends in Ecology and Evolution, 15, 5-7.

Greenwood, P.J. 1980. Mating systems, philopatry and dispersal in birds and mammals. Animal Behaviour, 28, 1140-1162.

Guinet, C., Jouventin, P. \& Weimerskirch, H. 1992. Population changes, movements of southern elephant seals on Crozet and Kerguelen archipelagos in the last decades. Polar Biology, 12, 349-356.

Guinet, C., Jouventin, P. \& Weimerskirch, H. 1999. Recent population change of the southern elephant seal at Iles Crozet and Iles Kerguelen: the end of the decrease? Antarctic Science, 11, 193-197.

HANSKI, I. 1999. Metapopulation ecology. Oxford: Oxford University Press, 328 pp.

Herreman, J.K., Blundell, G.M., McDonald, D.B. \& Ben-David, M. 2009. Asymmetrical male-mediated gene flow between harbor seal (Phoca vitulina) populations in Alaska. Canadian Journal of Zoology, 87, 498-507.

Hindell, M.A. \& McMahon, C.R. 2000. A long distance movement of a southern elephant seal (Mirounga leonina) from Macquarie Island to Peter I Øy. Marine Mammal Science, 16, 504-507.

Hoelzel, A.R., Campagna, C. \& Arnbom, T. 2001. Genetic and morphometric differentiation between island and mainland southern elephant seal populations. Proceedings of the Royal Society, B268, 325-332.

Hofmeyr, G.J.G. 2000. Dispersal and dispersion in the southern elephant seal Mirounga leonina at Marion Island. MSc dissertation, University of Pretoria, 181 pp. [Unpublished.]

HowARD, W.E. 1960. Innate and environmental dispersal of individual vertebrates. American Midland Naturalist, 63, 152-161.

Keith, M., Bester, M.N., Bartlett, P.A. \& Baker, D. 2001. Killer whales (Orcinus orca) at Marion Island, Southern Ocean. African Zoology, 36, $163-175$.

Kirkman, S.P., Hofmeyr, G.J.G., Bester, M.N. \& Isaksen, K. 2001. Counts of southern elephant seals, Mirounga leonina at Bouvet Island. Polar Biology, 24, 62-65.
Lenglart, P.Y. \& Bester, M.N. 1982. Post-weaning dispersion of southern elephant seal Mirounga leonina underyearlings at Kerguelen. Review de Ecologie (Terre et la Vie), 36, 175-186.

Lewis, M., Campagna, C. \& Quintana, F. 1996. Site fidelity and dispersion of southern elephant seals from Patagonia. Marine Mammal Science, 12, $138-147$.

Lewis, M., Campagna, C., Marin, M.R. \& Fernandez, T. 2006. Southern elephant seals north of the Antarctic Polar Front. Antarctic Science, 18, 213-221.

McConnell, B.J., Chambers, C. \& FedaK, M.A. 1992. Foraging ecology of southern elephant seals in relation to bathymetry and productivity of the Southern Ocean. Antarctic Science, 4, 393-398.

McMahon, C.R., Burton, H.R. \& Bester, M.N. 2003. A demographic comparison of two southern elephant seal populations. Journal of Animal Ecology, 72, 61-74.

McMahon, C.R., Bester, M.N., Burton, H.R., Hindell, M.A. \& Bradshaw, C.J.A. 2005a. Population status, trends and a re-examination of the hypotheses explaining the recent declines of the southern elephant seal Mirounga leonina. Mammal Review, 35, 82-100.

McMahon, C.R., Hindell, M.A., Burton, H.R. \& Bester, M.N. 2005 b. Comparison of southern elephant seal populations, and observations of a population on a demographic knife-edge. Marine Ecology Progress Series, 288, 273-283.

McMahon, C.R., Bester, M.N., Hindell, M.A., Brook, B.W. \& Bradshaw, C.J.A. 2009. Shifting trends: detecting environmentally mediated regulation in long lived marine vertebrates using time-series data. Oecologia, 159, 69-82.

Möller, L.M. \& Beheregaray, L.B. 2004. Genetic evidence for sexbiased dispersal in resident bottlenose dolphins (Tursiops aduncus). Molecular Ecology, 13, 1607-1612.

Nathan, R. 2001. The challenges of studying dispersal. Trends in Ecology and Evolution, 16, 481-483.

NicholLs, D.G. 1970. Dispersal and dispersion in relation to the birthsite of the southern elephant seal, Mirounga leonina (L.), of Macquarie Island. Mammalia, 34, 598-616.

Oosthuizen, W.C., Bester, M.N., De Bruyn, P.J.N. \& Hofmeyr, G.J.G. 2009. Intra-archipelago moult dispersion of southern elephant seals at the Prince Edward Islands, southern Indian Ocean. African Journal of Marine Science, 31, 457-462.

Oosthuizen, W.C., De Bruyn, P.J.N., Bester, M.N. \& Girondot, M. 2010. Cohort and tag-site specific tag-loss rates in mark-recapture studies: a southern elephant seal cautionary case. Marine Mammal Science, 26, 350-369.

Pistorius, P.A., Bester, M.N. \& Kirkman, S.P. 1999. Survivorship of a declining population of southern elephant seals, Mirounga leonina, in relation to age, sex, and cohort. Oecologia, 121, 201-211.

Pistorius, P.A., Bester, M.N., Kirkman, S.P. \& Taylor, F.E. 2001. Temporal changes in fecundity and age at sexual maturity of southern elephant seals at Marion Island. Polar Biology, 24, 343-348.

Pistorius, P.A., Bester, M.N., Lewis, M.N., Taylor, F.E., Campagna, C. \& KiRKMAN, S.P. 2004. Adult female survival, population trend, and the implications of early primiparity in a capital breeder, the southern elephant seal (Mirounga leonina). Journal of Zoology, 263, 107-119.

REISINGER, R.R. \& BESTER, M.N. 2010. Long distance breeding dispersal of a southern elephant seal. Polar Biology, 33, 1289-1291.

Setsaas, T.H., Bester, M.N., van Niekerk, J.H., Roux, J.P. \& Hofmeyr, G.J.G. 2008. Dispersion during the moult haulout of southern elephant seals at the Courbet Peninsula, Iles Kerguelen. Polar Biology, 31, 249-253.

Slade, R.W., Moritz, C., Hoelzel, A.R. \& Burton, H.R. 1998. Molecular population genetics of the southern elephant seal Mirounga leonina. Genetics, 149, 1945-1957.

Slip, D.J. \& Burton, H.R. 1999. Population status and seasonal haulout patterns of the southern elephant seal (Mirounga leonina) at Heard Island. Antarctic Science, 11, 38-47. 
Sмith, V.R. 2008. Energy flow and nutrient cycling in the Marion Island terrestrial ecosystem: 30 years on. Polar Record, 44, 211-226.

Tosh, C.A. 2010. Oceanographic signatures and foraging areas of southern elephant seals. $\mathrm{PhD}$ thesis, University of Pretoria, $151 \mathrm{pp}$. [Unpublished.]

Trakhtenbrot, A., Nathan, R., Perry, G. \& Richardson, D.M. 2005. The importance of long-distance dispersal in biodiversity conservation. Diversity and Distributions, 11, 173-181.
VAN Den Hoff, J. 2001. Dispersal of southern elephant seals (Mirounga leonina) marked at Macquarie Island. Wildlife Research, 28, 413-418.

VAn den Hoff, J., Davies, R. \& Burton, H. 2003. Origins, age composition and change in numbers of moulting southern elephant seals (Mirounga leonina) in the Windmill Islands, Vincennes Bay, East Antarctica, 1988-2001. Wildlife Research, 30, 275-280. 